J. Biosci., Vol. 3, Number 4, December 1981, pp. 361-370. (C) Printed in India.

\title{
Alterations in the activities of the enzymes of proline metabolism in Ragi (Eleusine coracana) leaves during water stress
}

\author{
RAJENDRA P. KANDPAL, C. S. VAIDYANATHAN, M. UDAYA \\ KUMAR*, K. S. KRISHNA SASTRY* and N. APPAJI RAO \\ Department of Biochemistry, Indian Institute of Science, Bangalore 560012 and \\ * Department of Crop Physiology, University of Agricultural Sciences, G.K.V.K. Campus, \\ Bangalore 560065 .
}

MS received 3 September 1981; revised 27 October 1981

\begin{abstract}
Free proline content in Ragi (Eleusine coracana) leaves increased markedly (6 to 85 fold) as the degree of water stress, created by polyethylene gylcol treatment, was prolonged There was also a marginal increase in soluble proteins in the stressed leaves as compared to that in the controls. Water stress stimulated the activities of ornithine aminotransferase and pyrroline-5-carboxylate reductase, the enzymes of proline biosynthesis and markedly inhibited the enzymes involved in proline degradation viz., proline oxidase and pyrroline-5-carboxylate dehydrogenase. These results suggest that increase in free proline content of Ragi leaves could be due to enhanced activities of the enzymes synthesizing proline but more importantly due to severe inhibition of the enzymes degrading proline. These observations establish for the first time, the pathway of proline metabolism in plants by way of detection of the activities of all the enzymes involved and also highlight the role of these enzymes in proline accumulation during water stress.
\end{abstract}

Keywords. Proline; water stress; Eleusine coracana; ornithine aminotransferase; pyrroline5-carboxylate reductase; proline oxidase; pyrroline-5-carboxylate dehydrogenase.

\section{Introduction}

A cascade of events, involving several biochemical changes is triggered by the withdrawal of water from plants. Although the early events following water stress are not clearly known, the most significant and immediately detectable change accompanying water stress is the accumulation of free proline. The free proline levels increase markedly in Bermuda grass and barley leaves during water deprivation (Barnett and Naylor, 1966; Kemble and Macpherson, 1954; Routley, 1966; Singh et al., 1973). It has been shown that a few drought resistant crop varieties accumulate more proline as compared to the drought susceptible varieties (Srinivasa Reddy and Sastry, 1977). A relationship between yield stability index and proline accumulation has also been shown in barley genotypes (Singh et al., 1972). These findings indicate that accumulation of proline may provide a biochemical adaptation for plants during water stress. Though several attempts have been made to establish a relationship between proline accumulation and drought tolerance, not much is known about the regulation of proline 
metabolism in plants grown under drought conditions. It is, therefore, of equal importance to study the regulation of this biochemical phenomenon in plants during water stress.

The biosynthesis and degradation of proline using radio-active precursors and detection of enzymes involved in these processes have been carried out in some detail (Boggess and Stewart, 1976; Boggess et al., 1976; Wright et al., 1977; Mazelis and Creveling, 1973; Boggess et al., 1975; Mazelis and Fowden, 1969; Huber, 1974; Stewart et al., 1977). However, all the enzymes involved in the biosynthesis and degradation of proline have not been reported in a single plant source and a comparative study of these enzymes have not been carried out in normal and water stressed plants.

With the objective of detecting enzymes involved in the conversion of ornithine to proline and exploring a cause-effect relationship between proline accumulation and drought resistance. Ragi (Eleucine coracana), a crop grown under rainfed conditions in Karnataka State, parts of which are drought-prone, was chosen for this study and the activities of the biosynthetic and degradative enzymes of proline metabolism were examined.

\section{Materials and methods}

\section{Materials}

All biochemicals were obtained from Sigma Chemical Co., St. Louis, Missouri, USA. Polyethylene glycol (6,000 molecular weight) was obtained from SD's Lab Chem Industry, Bombay. All other chemicals such as buffer components were of the analytical reagent grade and were obtained from British Drug House, Bombay.

\section{Plant material}

Ragi (Eleusine coracana) seeds var. Purna were obtained from the University of Agricultural Sciences, Bangalore. The seedlings were grown in the Institute nursery for a period of 60 days. Young and fully expanded leaves were used 45 to 60 days after germination. The leaf samples were collected randomly, pooled and divided into several sets for further treatments.

\section{Induction of stress}

Sets of leaves weighing $10 \mathrm{~g}$ each were taken. The control set of leaves was partly dipped in water to maintain them turgid. The water stress was created by partly dipping the cut end of leaves in $40 \%$ polyethylene glycol and exposing the leaves to two $100 \mathrm{~W}$ bulbs. The period of stress varied from 2 to $24 \mathrm{~h}$. The turgid tissue was also similarly treated for an identical period except that polyethylene glycol was replaced by water. At the end of each treatment the leaves were washed free of polyethylene glycol, blot-dried, cut into small pieces and chilled. The control set of leaves was also processed similarly. A total of four replications in duplicates were used for each treatment both in control and stress conditions.

Preparation of the homogenate for measuring the activities of ornithine aminotransferase and pyrroline-5-carboxylate reductase 
The leaves were ground in a cold pestle and mortar with glass powder (1:1 wt/wt) and 0.1 potassium phosphate buffer ( $\mathrm{pH}$ 7.4) containing $1 \mathrm{mM}$ pyridoxal-5phosphate; $1 \mathrm{mM}$ EDTA; and $10 \mathrm{mM}$-mercaptoethanol. The resulting slurry was filtered through cheese cloth yielding about $20 \mathrm{ml}$ of liquid. The filtrate was then centrifuged for $10 \mathrm{~min}$ at $12,000 \mathrm{~g}$ in a Sorval RC-5B centrifuge. The supernatant was collected and used for enzyme assays.

Preparation of the homogenate for measuring the activities ofproline oxidase and pyrroline-5-carboxylate dehydrogenase

The leaf tissue was ground in a cold pestle and mortar with glass powder $(1: 1 \mathrm{wt} / \mathrm{wt})$ and 0.1 potassium phosphate buffer $(\mathrm{pH} 7.4)$ containing $0.5 \%(\mathrm{v} / \mathrm{v})$ triton $\mathrm{X}-100$. The resulting slurry was filtered through cheese cloth and then centrifuged at 1000 $g$ for $10 \mathrm{~min}$. The supernatant was used for enzyme assays.

\section{Protein estimation}

The soluble proteins present in the leaf extract were precipitated with $10 \%$ trichoroacetic acid and the pellet dissolved in $\mathrm{O} .1 \mathrm{~N} \mathrm{NaOH}$. The proteins were estimated by the method of Lowry et al. (1951).

\section{Free proline estimation}

Free proline was estimated by the method of Bates et al (1973).

\section{Preparation of pyrroline-5-carboxylate and o-aminobenzaldehyde}

Pyrroline-5-carboxylate was prepared by enzymatic oxidation of proline using rat liver mitochondrial fraction (Johnson and Strecker, 1962). o-Aminobenzaldehyde was prepared by chemical reduction of o-nitrobenzaldehyde (Smith and Opie, 1955).

\section{Enzyme assays}

Ornithine aminotransferase: The assay mixture consisted of 0.1 potassium phosphate buffer ( $\mathrm{pH} 8.0$ ); $50 \mathrm{mM}$ ornithine; $20 \mathrm{mM}$-ketoglutarate; $1 \mathrm{mM}$ pyridoxal-5'-phosphate and enzyme in a total volume of $1.0 \mathrm{ml}$. After incubation at $37^{\circ} \mathrm{C}$, the reaction was terminated by adding $1.0 \mathrm{ml}$ of $10 \%$ trichlorocacetic acid. The colour was developed by adding $2 \mathrm{ml}$ of $0.5 \% \quad 0$-aminobenzaldehyde in $95 \%$ ethanol. The mixture was further incubated for $10 \mathrm{~min}$ and then centrifuged to remove the denatured proteins. The control tube was devoid of the enzyme extract. The product formed was determined by measuring the absorbance at 440 $\mathrm{nm}$ in a Pye-Unicam spectrophotometer. Enzyme activity units were calculated by using a molar extinction coefficient of $2.71 \times 10^{3} \mathrm{M}^{-1} \mathrm{~cm}^{-1}$ for pyrroline-5carboxylic acid.

\section{Proline oxidase}

The assay mixture consisted of $15 \mathrm{mM}$ L-proline; $0.01 \mathrm{mM}$ cytochrome c. 0.1 potassium phosphate buffer $(\mathrm{pH} 8.0) ; 0.5 \%(\mathrm{v} / \mathrm{v})$ triton $\mathrm{X}-100$; and enzyme extract in a total volume of $1.0 \mathrm{ml}$. The incubation was carried out at $37^{\circ} \mathrm{C}$ for $30 \mathrm{~min}$ and the reaction terminated by adding $1.0 \mathrm{ml}$ of $10 \%$ trichloroacetic acid. The colour 
was developed by incubating the reaction mixture with $2.0 \mathrm{ml}$ of $0.5 \%$-aminobenzaldehyde in $95 \%$ ethanol for $10 \mathrm{~min}$. The denatured proteins were removed by centrifugation and absorbance measured against a control at $440 \mathrm{~nm}$. The enzyme extract was not added in the control. Enzyme activity units were calculated as described for ornithine aminotransferase.

\section{Pyrroline-5-carboxylate dehydrogenase}

The enzyme activity was monitored by following the increase in absorbance of $\mathrm{NADH}$ formed at $340 \mathrm{~nm}$. The reaction mixture consisted of $1 \mathrm{mM}$ pyrroline-5carboxylate; $0.6 \mathrm{mM} \mathrm{NAD}{ }^{+} ; 0.1$ potassium phosphate buffer $(\mathrm{pH} 8.0) ; 0.5 \%$ $(\mathrm{v} / \mathrm{v})$ triton X-100 and enzyme extract in a total volume of $3.0 \mathrm{ml}$. The incubation was carried out at room temperature $\left(20-25^{\circ} \mathrm{C}\right)$. The enzyme activity was expressed as nmol of $\mathrm{NADH}$ formed $/ \mathrm{min} / \mathrm{g}$ fresh weight.

\section{Pyrroline-5-carboxylate reductase}

The enzyme activity was followed by measuring the decrease in absorbance at 340 $\mathrm{nm}$ due to oxidation of NADH. The reaction mixture consisted of $1 \mathrm{mM}$ pyrroline-5-carboxylate; $0.12 \mathrm{mM} \mathrm{NADH} ; 0.1$ potassium phosphate buffer $(\mathrm{pH}$ 7.4) and enzyme extract in a total volume of $3 \mathrm{ml}$. The reaction mixture was incubated at room temperature and the decrease in absorbance at $340 \mathrm{~nm}$ was followed. The enzyme activity was expressed as nmol of $\mathrm{NADH}$ oxidized $/ \mathrm{min} / \mathrm{g}$ fresh weight.

\section{Results}

\section{Protein content of the normal and polyethylene glycol treated leaves}

The protein content of the normal leaves which were just dipped in water increased from $17.38 \pm 0.65 \mathrm{mg} / \mathrm{g}$ fresh weight at $2 \mathrm{~h}$ to $21.79 \pm 0.23 \mathrm{mg} / \mathrm{g}$ fresh weight at $24 \mathrm{~h}$. The protein content of leaves treated with polyethylene glycol showed an increase over the control, which was detectable as early as $2 \mathrm{~h}$ after treatment. The increase was as much as $35 \%$ over the normal leaves, when the period of treatment was $8 \mathrm{~h}(\mathrm{P}=0.0001)$. Interestingly enough, soluble proteins were always greater in the stressed leaves. However, the values reached to those of the control on continuing the stress for $24 \mathrm{~h}$ (table 1$)$.

Table 1. Changes in the protein content of normal and stressed Ragi leaves.

\begin{tabular}{ccc}
\hline & \multicolumn{2}{c}{$\mathrm{mg} / \mathrm{g}$ fresh weight } \\
Period of PEG & $a$ \\
treatment $(h)$ & Normal leaves* & Stressed leaves* \\
\cline { 2 - 3 } & & \\
2 & $17.38 \pm 0.65$ & $19.38 \pm 0.87$ \\
4 & $18.61 \pm 0.21$ & $20.30 \pm 0.30$ \\
6 & $18.61 \pm 0.63$ & $22.61 \pm 0.65$ \\
8 & $19.95 \pm 0.86$ & $27.22 \pm 0.52$ \\
10 & $20.38 \pm 0.21$ & $27.22 \pm 0.75$ \\
12 & $20.76 \pm 0.43$ & $25.99 \pm 0.21$ \\
24 & $21.79 \pm 0.23$ & $22.69 \pm 0.43$ \\
\hline
\end{tabular}

\footnotetext{
* Mean of four replications in duplicates \pm standard deviation.

a Polyethylene glycol.
} 


\section{Increase in free proline content of the leaves subjected to water stress}

The free proline levels of the normal leaves varied between $71 \mu \mathrm{g} / \mathrm{g}$ fresh weight to $87 \mu \mathrm{g} / \mathrm{g}$ fresh weight. A very large increase in free proline level was observed in the leaves subjected to water stress. The stressed leaves had 6.5 fold more proline as early as $2 \mathrm{~h}$ after polyethylene glycol treatment. The accumulation of proline increased as the stress prolonged and attained maximal levels at $8 \mathrm{~h}$ after the polyethylene glycol treatment. The levels remained constant thereafter upto $12 \mathrm{~h}$ of the treatment. There was a marginal decrease in the accumulated proline $24 \mathrm{~h}$ after the treatment. However, the increase in proline was as much as 65 fold, even on continuing the treatment for $24 \mathrm{~h}$ (table 2).

Table 2. Free proline content of normal and stressed Ragi leaves

\begin{tabular}{|c|c|c|}
\hline \multirow{2}{*}{$\begin{array}{c}\text { Period of } \mathrm{PEG}^{a} \\
\text { treatment }(\mathrm{h})\end{array}$} & \multicolumn{2}{|c|}{$\mu \mathrm{g} / \mathrm{g}$ fresh weight } \\
\hline & Normal leaves* & Stressed leaves* \\
\hline 2 & $71.39 \pm 1.56$ & $465.42 \pm 21.63$ \\
\hline 4 & $72.48 \pm 3.70$ & $1109.39 \pm 15.70$ \\
\hline 6 & $74.71 \pm 2.64$ & $4020.40 \pm 14.87$ \\
\hline 8 & $82.10 \pm 4.36$ & $6939.90 \pm 31.88$ \\
\hline 10 & $80.80 \pm 0.60$ & $6427.08 \pm 14.41$ \\
\hline 12 & $84.53 \pm 1.76$ & $6322.79 \pm 14.87$ \\
\hline 24 & $87.23 \pm 2.73$ & $5969.13 \pm 6.93$ \\
\hline
\end{tabular}

* Mean of four replications in duplicates \pm standard deviation.

$a$ Polyethylene glycol.

\section{Ornithine aminotransferase}

The activity of ornithine aminotransferase varied from 78 to 133 units at various stages. The enzyme activity increased in leaves treated with polyethylene glycol The increase was detectable $2 \mathrm{~h}$ after the treatment. The enzyme activity was two times larger than in the normal tissue when the treatment was continued for $4 \mathrm{~h}$. The increase reached a maximum value of about 3.5 fold at $8 \mathrm{~h}$ of the treatment. Although the enzyme activity declined after $8 \mathrm{~h}$, it was always two fold greater than the respective control values (table 3 ).

\section{Pyrroline-5-carboxylate reductase}

The enzyme activity in the normal leaves varied between 62 to 87 units. The polyethylene glycol treated leaves exhibited an increase in pyrroline-5-carboxylate reductase activity as compared to the activity in the normal leaves. The increase in enzyme activity was proportional to the degree of water stress till $8 \mathrm{~h}$ of the treatment, when a maximum increase of about 2.5 fold was observed. An increase of about 1.5 fold was seen after $24 \mathrm{~h}$ of the treatment. The pattern of change in enzyme activity was similar to that obtained for ornithine aminotransferase (table 4). 
Table 3. Ornithine aminotransferase activity in normal and stressed Ragi leaves.

\begin{tabular}{|c|c|c|}
\hline \multirow{2}{*}{$\begin{array}{l}\text { Period of } \mathrm{PEG}^{a} \\
\text { treatment }(\mathrm{h})\end{array}$} & \multicolumn{2}{|c|}{ nmol of $\mathrm{P}-5-\mathrm{C}^{b}$ formed $/ \mathrm{min} / \mathrm{g}$ fresh weight } \\
\hline & Normal leaves* & Stressed leaves* \\
\hline 2 & $77.77 \pm 5.23$ & $144.44 \pm 5.22$ \\
\hline 4 & $94.44 \pm 13.09$ & $177.78 \pm 10.47$ \\
\hline 6 & $103.70 \pm 10.40$ & $289.43 \pm 0.77$ \\
\hline 8 & $114.07 \pm 2.61$ & $399.25 \pm 5.31$ \\
\hline 10 & $117.03 \pm 5.27$ & $385.18 \pm 20.95$ \\
\hline 12 & $124.44 \pm 0.00$ & $374.77 \pm 15.71$ \\
\hline 24 & $132.66 \pm 5.23$ & $268.89 \pm 10.50$ \\
\hline
\end{tabular}

Table 4. Pyrroline-5-carboxylate reductase activity in normal and stressed Ragi leaves.

\begin{tabular}{ccc}
\hline & \multicolumn{2}{c}{ nmol of NADH oxidized/min/g fresh weight } \\
\cline { 2 - 3 } Period of PEG $^{a}$ treatment $(\mathrm{h})$ & Normal leaves* & Stressed leaves* \\
\hline & & \\
2 & $62.20 \pm 9.77$ & $81.56 \pm 1.95$ \\
4 & $67.73 \pm 5.86$ & $106.44 \pm 1.09$ \\
6 & $73.26 \pm 1.95$ & $138.24 \pm 10.55$ \\
8 & $74.64 \pm 3.91$ & $171.42 \pm 11.73$ \\
10 & $81.56 \pm 1.05$ & $145.15 \pm 17.59$ \\
12 & $85.70 \pm 3.29$ & $131.33 \pm 9.77$ \\
24 & $87.24 \pm 7.82$ & $127.18 \pm 3.91$ \\
\hline
\end{tabular}

* Mean of four replications of duplicates \pm standard deviations.

a Polyethylene glycol.

\section{Proline oxidase}

The activity of proline oxidase in normal leaves varied from 40 to 44 units at various stages. There was a remarkable decrease in the enzyme activity in stressed leaves. The stress resulted in 50\% decrease of enzyme activity at $4 \mathrm{~h}$ of the treatment. The enzyme activity was barely detectable after $8 \mathrm{~h}$ of treatment. The decrease in the activity was as much as 60 to 80 fold at later stages of water stress (table 5).

\section{Pyrroline-5-carboxylate dehydrogenase}

The enzyme activity in the normal leaves ranged between 61 to 75 units. The pattern of change in pyrroline-5-carboxylate dehydrogenase activity was similar to that followed by proline oxidase, though the magnitude of change was not as large. The enzyme activity decreased by about two fold at $6 \mathrm{~h}$ of the treatment. The decrease was more pronounced at advanced stages of the treatment. The decrease was as marked as 15 fold in leaves treated with polyethylene glycol for 12 h (table 6). 
Table 5. Proline oxidase activity in normal and stressed Ragi leaves.

\begin{tabular}{ccc}
\hline & \multicolumn{2}{c}{ nmol of $\mathrm{P}-5-\mathrm{C}^{b}$ formed $/ \mathrm{min} / \mathrm{g}$ fresh weight } \\
\cline { 2 - 3 } $\begin{array}{c}\text { Period of } \mathrm{PEG}^{\mathrm{a}}{ }^{\mathrm{t}} \\
\text { treatment (h) }\end{array}$ & Normal leaves* & Stressed leaves* \\
\hline & & \\
2 & $40.74 \pm 1.04$ & $34.44 \pm 1.56$ \\
4 & $41.11 \pm 0.25$ & $22.22 \pm 2.09$ \\
6 & $42.22 \pm 0.53$ & $1.03 \pm 0.21$ \\
8 & $44.81 \pm 0.70$ & $0.59 \pm 0.00$ \\
10 & $44.94 \pm 0.35$ & $0.59 \pm 0.00$ \\
12 & $42.51 \pm 0.23$ & $0.74 \pm 0.00$ \\
24 & $44.04 \pm 4.70$ & $0.88 \pm 0.00$ \\
\hline
\end{tabular}

* Mean of four replications in duplicates \pm Standard deviation.

a polyethylene glycol.

$b$ pyrroline-5-carboxylate.

Table 6. Pyrroline-5-carboxylate dehydrogenase activity in normal and stressed Ragi leaves.

\begin{tabular}{|c|c|c|}
\hline \multirow{2}{*}{$\begin{array}{c}\text { Period of } \mathrm{PEG}^{a} \\
\text { treatment }(\mathrm{h})\end{array}$} & \multicolumn{2}{|c|}{$\mathrm{nmol}$ of $\mathrm{NADH}$ formed $/ \mathrm{min} / \mathrm{g}$ fresh weight } \\
\hline & Normal leaves* & Stressed leaves* \\
\hline 2 & $60.95 \pm 4.10$ & $47.61=3.83$ \\
\hline 4 & $63.86 \pm 2.73$ & $37.73 \pm 1.36$ \\
\hline 6 & $67.73 \pm 2.74$ & $32.86 \pm 2.73$ \\
\hline 8 & $68.70 \pm 6.83$ & $13.54 \pm 2.73$ \\
\hline 10 & $71.99 \pm 2.18$ & $7.74 \pm 0.20$ \\
\hline 12 & $74.51 \pm 1.37$ & $5.80 \pm 0.74$ \\
\hline 24 & $72.57 \pm 0.83$ & $21.28 \pm 5.58$ \\
\hline
\end{tabular}

\section{Discussion}

A wide array of events occur when water is withheld from plants (Hsio, 1973) Several methods which range from withdrawal of water to plants to the use of chemicals such as polyethylene glycol, mannitol etc., have been employed to create water stress in plants. It has been reasonably well established that polyethylene glycol induced water stress mimics that caused by withdrawal of water from plants (Todd, 1972).

It is evident from the results presented in this paper that the metabolism of Ragi plants responds to the changes in the availability of water. The change in the soluble proteins of the normal leaves over a period of $24 \mathrm{~h}$ reflects continuous metabolism occurring in the leaves maintained in turgid conditions. A similar pattern of changes in soluble proteins was observed by Singh et al. (1973). 
Increased proteolysis and inhibition of protein synthesis have been reported in plants during water stress (Kemble and Macpherson, 1954; Petrie and Wood, 1962). While in most instances a decrease in protein content is noticed during water stress (Vaadia et al., 1961; Shah and Loomis, 1965; Stutte and Todd, 1969), fluctuations in protein content have also been recorded (Chen et al., 1964). The increase in protein levels of leaves subjected to water stress, observed by us could be due to (a) increased de novo synthesis and (b) decreased protein degradation or turnover. These alternatives need to be further probed into. In addition to a functional role, the increase in proteins, presumably, helps preserve the leaf structure during the process of wilting. This may represent a survival mechanism for Ragi, a crop grown under rain-fed conditions, has evolved to withstand extreme conditions of water stress.

It is clear from table 2 that proline levels are very high at every period of water stress, stretching over $24 \mathrm{~h}$. Our results depicting proline accumulation are in agreement with other reports (Barnett and Naylor, 1966; Kemble and Macpherson, 1954; Routley, 1966; Singh et al., 1973). The greater accumulation of proline in these genotypes, presumably, render them drought tolerant. This hypothesis is being tested at the present time. An increase in soluble proteins during water stress and the dramtic increase in the proline levels compared to other amino acids in the free amino acid pool clearly suggest that the contribution of proteolysis may not be the major factor responsible for this phenomenon. A possible reason for these increased levels of proline during water stress could be an alteration in the activities of the enzymes involved in the biosynthesis and degradation of proline. The pathway for the biosynthesis and degradation of proline as established in micro-organisms is shown in figure 1.

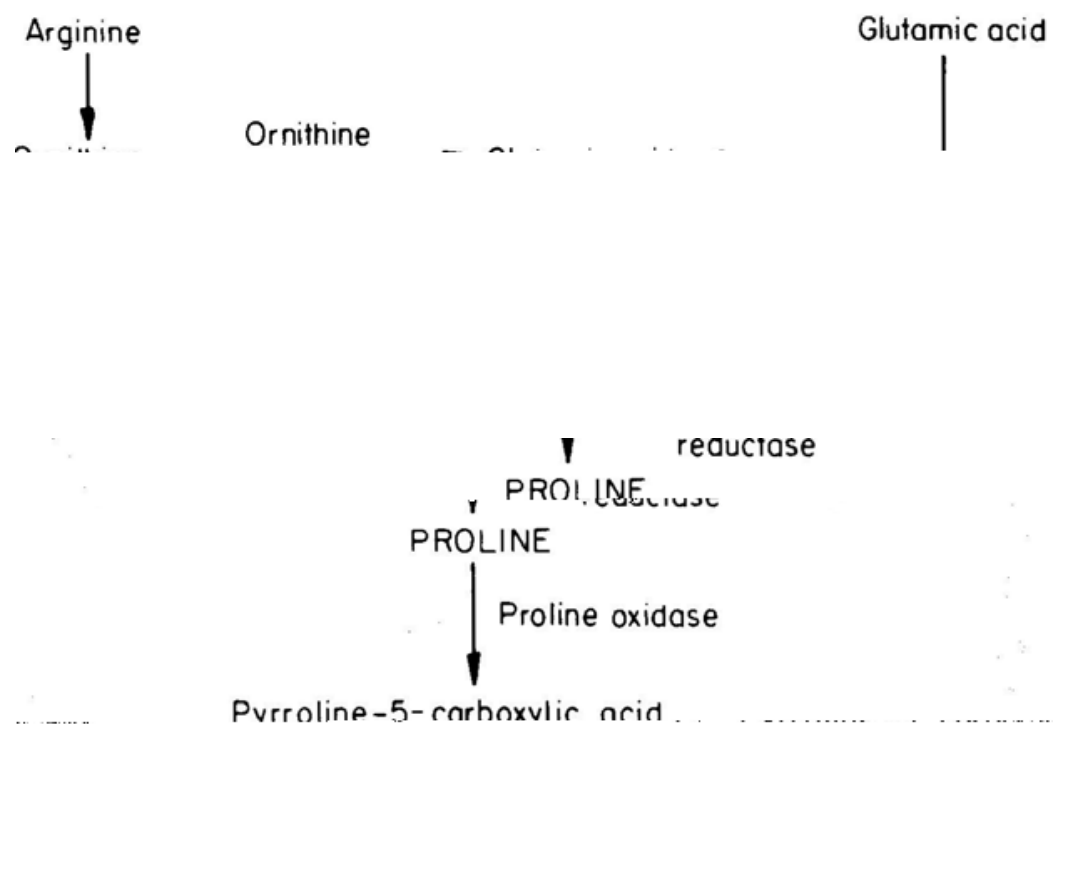

Figure 1. Pathway for proline metabolism. 
The detection of various enzymes of pathway metabolism for the first time in any plant system, clearly suggests the operation of this pathway in plants. The results presented in this study show that the activities of ornithine aminotransferase and pyrroline-5-carboxylate reductase increase by about 3.5 and 2.5 fold respectively suggesting that enhanced synthesis of proline may be occuring due to increased activities of these enzymes during water stress. Concomittantly, the activities of enzymes responsible for the degradation of proline viz., proline oxidase and pyrroline-5-carboxylate dehydrogenase decrease dramatically. These two factors together, probably, result in the increased levels of proline. Our results at the present time cannot distinguish between the two alternatives responsible for this phenomenon viz., (i) structural modification of 
Petrie, A. H. K. and Wood, J. G. (1962) Ann. Botany NOS., 2, 887.

Routley, D. G. (1966) Crop Sci., 6, 358.

Shah, C. B. and Loomis, R. S. (1965) Physiol. Plant., 18, 240.

Singh, T. N.. Aspinall, D. and Pal eg, L. G. (1972) Nature (London), 236, 188.

Singh, T. N.. Paleg, L. G. and Aspinall, D. (1973) Aust. J. Biol. Sci., 26, 45.

Smith, L. I. and Opie, J. W. (1955) Organic Synthesis, 3, 56.

Srinivasa Reddy, V. and Krishna Sastry, K. S. (1977) Curr. Sci., 46, 646.

Stewart, C. R., Boggess, S. F., Aspinall, D. and Paleg, L. G. (1977) Plant Physiol., 59, 930.

Stutte, C. A. and Todd, G. W. (1969) Crop Sci., 9, 510.

Todd, G. N. (1972) in Water deficit in plants, ed. T. T. Kozlowski (New York: Academic Press) p. 77

Vaadia, Y., Raney, F. C. and Hagen, R. M. (1961) Ann. Rev. Plant Physiol., 12, 265.

Wright, L., Wrench, P., Hinde, R. W. and Brady, C. J. (1977) Aust. J. Plant Physiol., 4, 51. 